\title{
The Influencing Factors of Computer Adoption in Agribusiness: A Preliminary Study
}

\author{
Sudaryanto \\ University of Jember, Indonesia
}

\section{ARTICLE INFO}

Received: April 02, 2011

Final revision: July 07, 2011

\section{Keywords:}

agribusiness,

ICT-computer,

multi-stages sampling,

logistic regression,

East Java.
A B S T R A C T

This research is aimed to investigate factors that influence the intentions of adopting computer for business purpose, and their implications on managerial development. Semi structured interview and courier mailed survey had been employed to collect the data. A conceptual framework and theoretical insight presented based on literature review and primary data collected from the various east java agribusiness. To develop qualitative information of sample characteristics, cross tabulation was employed. Logistic regression was used to test the research hypotheses. The research findings show that the intention to adopt computer in east java agribusiness is strongly influenced by managers whose ages are $41+$, education (TAFE/D3), and sales volume. This research has a direct implication on agribusiness development for the overall east java agribusiness and provinces in Indonesia. It is expected that it will encourage other researchers to conducting similar research benchmarking with other developing countries. The complexity and wide range of agribusiness term made the research methodology complicated.

(C) 2011 IRJBS, All rights reserved.

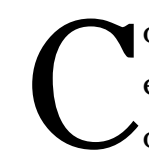
omputer technology has been introduced in early 1970 s and created significant impacts on business. Automation business through out Computer Aided Development (CAD) revolutionises the business and management system in any sectors from manufacturing to marketing activities. The role of Computer were then jump to the most sophistitcated technology as a business means by mid of 1990s when its connected to the internet.

Facilitated by famous portal namely Netscape. com, the Computer technology is becoming a commercial tool on mediating the business. The portal started to receive digital advertisement 
from many big companies and introduces to the public. The scholar has ever predicted that the growth of the business exponentially impacted by the technology. Hence, the issue of Computer adoption has recently become a priority for supporting agribusiness development in the globalization era (Salampasis, Batzios et al. 2002).

The Computer technology adopted to business creates the Value added (Deodar 2001; FAO 2001) The computerised value creation such as selling and searching agricultural information online leads agribusiness to global market. Palvia (1997) points out that Information and Communication Technology (ICT) can motivate companies to improve their performance and can propel and accelerate the globalization of business either in developed or in developing countries. In Indonesia's case with very cheap labour resources, adopting new technology such as ICT can produce productivity gains more related to better and more effective use of capital rather than to labour saving. The definition of ICT adopted in this paper is the sophisticated information communication and technology using electronic means to capture store and report to the other parties. This definition does not include one way types of communication, such as radio, TV and video (Sudaryanto, 2010).

East java one out of 33 provinces in Indonesia has become the centre for agriculture, which includes food crops, horticulture (tree crops), livestock and fisheries since 1995 . The province produces about 35 per cent of the Indonesian national food supply. Some commodities such as rice, sugar cane, coffee, tobacco, rubber, cocoa an fruit are the other priority agricultural products. Moreover, the province of East Java makes a significant contribution to the national economy and especially to the agro-industry sectors in Indonesia. This is reflected by the Regional Gross Domestic Product (GDRP) of the province. During 2002, East Java's GDRP was Rp. 227 trillions (CBS 2002). The agribusiness sector contributed 19 pe cent of this GDRP.
In relation to the regional economy (Otonomi Daerah), it is important for East Java to improve regional economic growth on agricultural based business. This can be done by increasing efficiency of the agricultural industry through the effective adoption of the most up-to-date technology. The agribusiness productivity theoretically is influenced by many factors such as labour, capital and technology. The widespread application by farmers of sophisticated computer technology enables some countries to derive efficiencies in areas such as bookkeeping, planning capital expenditures, pest control, pricing strategies and internet possibilities.

To support agribusiness productivity, the Indonesian government, under the Ministry of Agriculture (MOA) has been embracing many parties to increase agribusiness productivity by mechanization and diffusion of technology. Mechanized technology including on-field technology (tractor, breeding and harvesting machinery), and off-field technology like Computer Aided Development (CAD) and have the aim of improving output value. For the plan to succeed, it is important to study what factors potentially support or are roadblocks to this process. The focus of the study is to answer the question of what are the common factors influencing on intention to adopt Computer for business?

In recent studies, the factors that determine user acceptance of any information technology and, in particular, factors that relate to the basic traditional diffusion theory encourage researchers to focus outside the classical innovation diffusion model based around organisations developed by Rogers (1995). Scholars in the field of ICT have drawn heavily on theoretical work in social and cognitive psychology, as well as sociology, in studying user acceptance. This phenomenon is argued by Bandura (1986) in his CognitiveSocial Theory which constructs the "outcome expectancy", which refers to what the subject believes is the likely consequence of the execution of the behaviour. Thus, it is a concept of user acceptance in information technology which relates behaviour with contingent stimuli. For the purposes of this current study, a distinction has been drawn between the theoretical approaches seeking to understand the social environment from an organisational approach (e.g. Rogers, 1995) and the psychological determinants of owner-managers from the individual approach (e.g. Bandura, 1986).

A recent study of Computer adoption conducted in agriculture was done by Batte (2003). He conducted research on the use of computers for agriculture on Ohio farms. The study clearly identified implications for agribusiness development as most US farmers use a computer. Its adoption is influenced by individual factors such as age and education. Likewise, Bourakis, Kourgiantakis and Migdalas (2002) studied the individual factors in the adoption of acceptance of new technology where Crete's agricultural cooperatives used e-commerce for agro-food marketing. This study confirmed that ICT provides a significant contribution to marketing activities.

In Indonesia, before this research project had been proposed in 2005, there had not been many studies in ICT adoption and diffusion in Indonesia. An initial study concerning the importance of ICT for agribusiness had been conducted by Djojomartono and Pertiwi (1998). Using a qualitative research method, this research advised that farmers need an affordable ICT to be able to increase agricultural value. Nainggolan (2001) highlights the important of agribusiness-market information as a strategic way to access to global markets. Information about the dynamics of customer preferences, competitors and new products, needs to be analysed as a basis of formulating good planning and marketing strategy. He recommends a urgent development of agribusiness/market information system to link and match the supply in rural areas to demand in the cities. This phenomenon was in line with the TKTI campaign and initiated e-agribusiness development with some other institutions such as UNDP, APDIP, APJII and UNESCAP supporting the campaign.

Hermana, Sugiharto, and Margianti (2006). They conducted a preliminary study in Indonesian SMEs in which the participants were SMEs owner-manager undertaking ICT training programmes. Hermana et al. (2006) proposal wa an ICT adoption model which consisted of seven predictors; including performance expectancy, effort expectancy, social influence, facilitatin condition, self-efficacy, Internet anxiety, and perceived cost. Exploratory Factor analysis wa the only statistical analysis they used. The issue of ICT adoption in SMEs in Indonesia has become an important topic. Kartiwi (2006) investigated the factors and combination of factors that SMEs, especially those in the service sector, need to consider before embracing e-commerce. Based upon a qualitative study, she underline that SMEs in Indonesia lack in-house expertise. The importance of continuing support from the government or any non-government organisation in providing more comprehensive assistance to guide SMEs adoption in the whole process is strongly recommended in Kartiwi (2006).

The following year, Wahid (2007) investigate factors affecting Internet adoption as well as examining the differences in Internet usage patterns between men and women in Indonesia. Undertaking data analysis based on response from 714 students with various backgrounds, he found that Internet adoption among women is lower than among men. Furthermore, Wahid (2007) used the TAM model and found that Internet adoption among women is affected by perceived ease of use rather than perceived usefulness. In contrast, among men adoption is affected by perceived usefulness rather than perceived ease of use. In addition, Wahid investigated the high cost of Internet access, the low access speed of the Internet and a lack of English proficiency as the obstacles of Internet adoption in Indonesia. 
Many research studies indicated some factors that have significan impact on the Computer adoption such as Company's characteristics, organisational culture and demographic charatceristics. These variables were used to identify the factors influencing on intention to adopt Computer in Eas Java agribusiness.

\section{a) Companies Characteristics}

Some scholars doing research on compute adoption has mentioned that a different area of agriculture has different preferences on adopting computer technology (Putler and Zilberman 2001) Putler and Zilberman (2001) in Tulare County, California have shown that livestock producers are much more likely to use computers for production decision rather than crop producers. Similar research has been done by Ernst and Tucke (2002) with the findings that larger farms in both livestock and crops tend to adopt computers and ICT rapidly. Batte (2005) on his study mentioned that livestock producers spend less hours on using the computer than crop On the other hand, the size of company has also influence on intention to adopt computer (Jarvis 1990; Baker 1992; Amposah 1995)

H1: Types of business influence on intention to adopt Computer in East Java agribusiness

H2: Size of business has significant influence on intention to adopt Computer in East Java agribusiness

Amposah (1995) on his research on the use of computer in North Carolina had a conclusion that increasing farm size will encourage farmers to adopt computer. The other scholar, Baker (1992) on his research on factor influence on Computer adoption in nonfarm New Mexico agribusinesses, indicate that computer adoption is related to firm characteristics such as size and type of business. Similarly, Gloy and Akridge, (2001) have findings that in large US farms, the type of the companies has no significantly influence on Computer adoption, instead, gross sales has the influence.
This phenomenon may possibly be in operation in East Java agribusiness which has similar diversity in agriculture business such as food crops, tree crops, livestock, and fisheries.

H3: Sales have significant influence on intention to adopt Computer in East Java agribusiness

\section{b) Organizational Culture}

Lim (2004) has found that cultural differences impact on online activity. The concept of culture could be individual, social and organizational (Hofstede 1991). Organizational culture is the term that relates to race (black and white), export oriented, family relationship and ICT knowledge background. Those factors have a strong relationship to computer adoption (Gloy and Akridge 2001; Putler and Zilberman 2001).

East java culture has an explicit open minded approach, mostly dominated by Maduranese and East Javanese ethnic. Some scholars have analysed ICT literacy and company's business orientation as part of organizational culture (Putler and Zilberman 2001; Salampasis, Batzios et al. 2002; Mbowa and Mugisha 2004; Batte 2005). Mbowa and Mugisha (2004) did not involve race as an explanatory variable, but rather examined IT literacy of business operators and found that this contributed significantly to computer ownership. The other organizational cultural factors in agriculture sector found in small and medium business; are family relationships and association membership. One major dimensions is individualism as people in a culture prefer to act as individuals, rather than as a members of groups (Hofstede 1991). Managers involvement has influence on Computer adoption (Jarvis 1990).

H4: Family membership has significantly influence on intention to adopt Computer in East Java agribusiness

H5: Association membership has significant influence on intention to adopt Computer in East Java agribusiness
H6: ICT literacy has significantly influence on intention to adopt Computer in East Java agribusiness

H7: Managers involvement influence on intention to adopt Computer in East Java agribusiness

East java farmers are assumed to be quick adopters of new technology that could potentially improve productivity. However, demographic characteristics of the owner manager as an influence factors needs to be investigated. Putler and Zilberman, (2001), Batte (2005) and Salampasis et al.,(2002), Mbowa and Mugisha (2004) and also Ernst and Tucker (2002) pointed out that the demographic characteristic of owner manager has significantly influence on ICT-based Computer adoption

\section{c) Demographic Characteristic}

The demographic characteristic in most research tracks the influence of core variables. Thus, race, age, genders, income and education are most cited as "classic adopter" variables (U.S. Doc, 2000 in Earnst and Tucker 2002). Ernest and Tucker (2001) found no significance for age, economic factor and education in predicting adopter status in the fruit and vegetable industry, while gender was statistically significant. The other scholar mentioned that manager's education level has significant influence on Computer adoption (Jarvis 1990; Amposah 1995; Batte 2003).

H8: Age has significant influence on intention to adopt Computer in East Java agribusiness H9: Gender has significant influence on intention to adopt Computer in East Java agribusiness

H10: Manager's Education has significant influence on intention to adopt Computer in East Java agribusiness

In term of manager's ages, Putler and Zilberman, (2001) argued that age has a significant effect on Computer adoption. The pattern of adoption increase up to age group of 36-40, then adoption begins to decrease with age. In this research, the demographic characteristics identified as the age, gender, and education. While Batte (2003) has research finding that farmers who work in large farm has a higher education level and tends to use Computer due to the higher competition. Contradictory, Jarvis (1990) on his research in nonfarm New Mexico agribusinesses, indicate Computer adoption was unrelated to manage characteristics, including age and education.

\section{METHODS}

This research was conducted based on an explanatory research design. Explanatory research can be defined as a method or style of research in which the main objective is to know and understand the trait and mechanisms of the relationship and association between the independent and dependent variable (Veal 2006). In explanatory research, investigators attempt to test the hypothesis based on some previous study. The focus of the study identifies factors that have the most significant influence on decision making process on intention to adopt Compute for business. Since the outcome variable was dichotomous, a binary logistic regression model was used.

\section{a) Sampling Frame and Sampled Population}

The study's sample comprises 178 on-farm agribusiness (agro industry) owner managers from four agricultural areas (horticulture, fisheries, livestock and crops) in the East Java province There are 29 counties and eight municipalities, and two administrative cities. From these counties, a multi stages sampling method was used to minimize cost. The target population in the first stage referred to East Java's economic development planning document. The region is divided into four clusters: (1) North-South Bank (Koridor Utara Selatan) includes Gresik, Surabaya, Sidoarjo, Mojokerto, Pasuruan, Malang, Blitar. (2) Nort-West Bank (Koridor Barat Daya) includes Jombang, Kediri, Tulungagung, Trenggalek, 
Nganjuk, Madiun, Ponorogo, Pacitan, Magetan. (3) East Bank (Koridor Timur); Probolinggo, Situbondo, Bondowoso, Lumajang, Jember, Banyuwangi (4) North Bank (Koridor Utara); Lamongan, Tuban, Bojonegoro, Ngawi, Bangkalan, Sampang, Pamekasan, Sumenep.

Two clusters chosen conveniently were NorthSouth Bank and East Bank where there are many big universities such as University of Airlangga (UNAIR), "Institute Technology of Sepuluh Nopember" (ITS), Brawijaya University (UNIBRAW) and University of Jember (UNED) settled in these two cluster areas. All three universities have their responsibility to improve agribusiness performance and ICT adoption as part of "Three Points University's responsibilities" called "Tri Dharma Perguruan Tinggi" in which i involves the public services, teaching and research.

In the second stage involved choosing randomly two counties within two groups. For the Eas Group, the chosen counties were Banyuwang and Jember while the North South group were Malang and Sidoarjo. Among the four counties, the first three have a variety of agricultural products. The farm population in the four areas is 272

Table 1. The Valid Response distribution per types of business in selected counties

\begin{tabular}{llrrrrr}
\hline & & \multicolumn{3}{c}{ Address } & Total \\
\cline { 3 - 6 } & & Jember & Banyuwangi & Malang & Sidoarjo & \\
\hline holticulture & Count & 20 & 11 & 16 & 9 & 56 \\
\hline & \% within type of business & $35.7 \%$ & $19.6 \%$ & $28.6 \%$ & $16.1 \%$ & $100.0 \%$ \\
\hline fisheries & Count & 18 & 13 & 19 & 16 & 66 \\
\hline & $\%$ within type of business & $27.3 \%$ & $19.7 \%$ & $28.8 \%$ & $24.2 \%$ & $100.0 \%$ \\
\hline lifestock & Count & 12 & 7 & 11 & 2 & 32 \\
\hline & \% within type of business & $37.5 \%$ & $21.9 \%$ & $34.4 \%$ & $6.3 \% *$ & $100.0 \%$ \\
\hline Crops & Count & 7 & 7 & 6 & 4 & 24 \\
\hline & \% within type of business & $29.2 \%$ & $29.2 \%$ & $25.0 \%$ & $16.7 \%$ & $100.0 \%$ \\
\hline Total & Count & 57 & 38 & 52 & 31 & 178 \\
\hline & \% within type of business & $32.0 \%$ & $21.3 \%$ & $29.2 \%$ & $17.4 \%$ & $100.0 \%$ \\
\hline
\end{tabular}

* Quota was not achieved the target due to low responses
That number is adopted from the agro industry database which is published by The Ministry of Agriculture 2005.

The last was designed to obtain a 10 per cent quota to ensure cross section regress-able. The total sample is 200 respondents. The response rate is 178 (89 per cent) from the sample population with the distribution presented in the following Table 1.

\section{b) Data Collection and Analysis}

This research was conducted in between July to October 2006 in East Java. The questionnaire was developed by the researchers and distributed to the agricultural managers one by one. A pilot survey was done to test the questionnaire. Using combined method - mailed and semi structure interview - the survey was carried out in this dual form in order to maximise response rate. Ten trained final-year students were employed under tight supervision attached in the area to get the primary data.

Students knocked on the door one by one and made an appointment first with the owner/ manager. When the respondent did not have time from each area and each type of business in order to be interviewed, then the interviewer would let the owner/manager fill in the questionnaire in their own free time. The instructions to do complete the form are explained on each section of the questionnaire. After two weeks, the student would collect the questionnaire from the owner/ manager. This technique counted for 65 the per cent of the total response. The rest (35 per cent) had been investigated by the interviewers by asking the managers whether they had time to be interviewed. When they were ready, the interviewer then asked them to response to the questions.

\section{c) The Questionnaire}

Using combination between open and closed questions, the questionnaire was divided into four sections: (1) the organizational cultures, (2) owner/manager's demographic and (3) company profile. The first three sections are the qualitative information about managerial and organizational characteristics. This information was used to investigate the factors which influence on intention to adopt Computer in East Java agribusiness. The specific measures used within the instrument are explained later in the paper

\section{Analytical Data}

\section{a) Logistic Regression Mode}

Logistic regression (Logit) is a statistical tool as part of statistical models namely Generalized Linear Models (GLM) which produces predictive equations. Logit allow for prediction of discrete outcome - which mostly dichotomous as a dependent variable - and set of various types of independent variables - such as continuous, discrete, dichotomous - taking on two or more possible values (Hosmer and Lemeshow 1989, p.1).

Logit is still different with Ordinary Least Square regression (OLS) in the choice of parametric model and the assumptions. In particular there is the assumption that OLS data inquiry should be normally distributed and limited to types of variables that are either independent or dependent one. The OLS needs either an ordinary or nominally dependent variable, while in Logit the dependent variable normally is dichotomous, but it could be categorical, nominal and ordina Although OLS regression estimation is unbiased the estimation is not efficient. The OLS has also problematic because the assumptions of OLS are violated when using a binary response variable. Therefore, in deciding whether the researcher will use either OLS or Logit is depending on the expected outcomes. The $0 / 1$ outcome is turned into the grouping variable while in OLS a forme predictors are turned into outcome variables.

The research that has been done by Pohlmann (2003) had a conclusion whether both models can be used to test the relationship with a binary criterion, but logistic regression is superior to OLS on predicting the probability of attribute. He then recommended that logistic regression should be the model of choice for binary dependen regression analysis.

There are two types of simultaneous equations to control to the interrelationships between dependent variables in addition to single-equation i.e. ordinary least squares (OLS) and logistic regression models. We use Logit not OLS as its characteristics of the model in which one or more variables are binary (dummy) (Kmenta 1971, p. 425; Hosmer and Lemeshow 1989, p.1.) The following model is the Logit equation for the research. The Logistic regression model will be such as follow:

$\ln \left(\frac{p}{1-p}\right)=\beta_{0}+\beta_{1}$ xassoc $+\beta_{2} \chi$ family $+\beta_{3} \chi$ involved $+\beta_{4}$ xliteracy $+\beta_{5}$ xgender

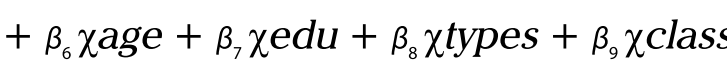
$+\beta_{10} \chi \log$ sales $+\varepsilon_{i}$

Where $I n$ is natural logarithm, $p$ is the probability of adopting Computer; $\beta_{0}$ is constant value, $\beta$ 
are parameters to be estimated; $y_{i}=\left(\frac{P}{1-P}\right)$ is dependent variables on ICT adoption that takes on a value of yes $=1$ if the responden adopt Computer or 0 if otherwise. assoc is the dichotomy variable $(1 / 0)$ of group membership of the companies, $\chi$ family is dummy $(1 / 0)$ variable of employees family relationship $(<\%)$ $\chi$ literacy is the scale variable of ICT literacy of the manager's and employees $(1=$ very weak, $5=$ very strong), $\chi$ involved is binary ( $1 / 0)$ variable of manager involvement in daily activities, $\chi$ gender is dycothomy variable $(1=$ male, $2=$ female $), \chi a g e$ is dummy variable $(1 / 0)$ with reference category age $41+, \chi e d u$ is dummy variable $(1 / 0)$ of education of the manager with reference category TAFE, $\chi$ types is four types of business (categorical) $\chi$ class is dummy variable $(1 / 0)$ with reference category large business, $\chi$ saleslog is $\log 10$ of gross sales volume the last semester (continuous), $\varepsilon$ is assumed to be a standard normal.

\section{b) Expected Output}

The outcome of this model will be the significan probability how the dependent variables decide to adopt Computer $=1$, or not adopted $=0$. The explanatory variables will produce the significan probability on influencing Computer adoption. Therefore the Logit will test the following hypothesis:

Accept $H_{a}$ if 0.05 with the lowest level of significant 95\% (Phillip 2003)

Exploratory data analysis (EDA) was conducted to test skewness, kurtosis and data distribution of continuous variables. A Jarque-Beta tes had been done to check the normality for all continuous variables, while categorical variables had been tested using cross-tabulation. Both Pearson correlation and Fisher test produce the significant value which reflects the relationship between Computer and explanatory variables. Neither continuous variables nor categorical data showed that the data were normally distributed and therefore had to be transformed. Before the decision to make a dummy variable, the data re-categorized to produce a better distribution. The reference category then being concern to creates the dummy variables. While the continuos variables then been smoothing using $\log 10$ transformation.

\section{RESULTS AND DISCUSSION}

\section{a) Bivariate Analysis}

The result of cross tabulation found a significant association between the owner/manager's age and Computer adoption $\left(x^{2}=5, \mathrm{df}=2, p<.05\right)$. The term of Computer as a Portable Computer (PC) will not so attract young age's manager as a decision maker. This is associated with the research finding of Putler and Zilberman, (2001) and Batte (2003). The Computer adoption tends to be accepted on the range of $41-50$ (27.9\%). The rest are not to adopt Computer with the highest percentages on the range of ages 21-40 (92.6\%). The multi variate analysis result is presented in Table 3.

Education level indicated for having significant relationship with the Computer adoption $\left(x^{2}=5, \mathrm{df}\right.$ $=1, p<.01)$. TAFE level is the highest probability association. The higher the level of education they were not likely to adopt Computer or PC. This figure will support research finding by Amposah (1995) against Batte (2003) and Jarvis (1990). The education level of managers has relevancy with ICT literacy in which it has a mean value 2.81 (3 $=$ average) and skewness -.188 . While gender has likely associated with Computer adoption $\left(x^{2}=5\right.$, $\mathrm{df}=1, p<.05)$ and dominated by female with CI 95\% (.001). This figure against research findings by Brown (2005) that there were no significant differences on using ICT for internet banking.

In particular organizational culture, the term of "individualism" defined by Hofstede (1991) did not apply in EJOVA. They tend to be collective rather then act individually on Computer adoption with family relationship significant $\left(x^{2}=5, \mathrm{df}=3, p<\right.$ .01 ). The highest percentage belongs to family relationship of the employee in between $21-30 \%$.
It supports Jarvis (1990) research finding that decision on adopting Computer are associated with action of peers and family. In contrast, an association membership such as agricultural cooperatives field-farmers association did not have any association with Computer adoption. Manager's involvement on the field indicated a significant association with Computer adoption

$\left(x^{2}=5, \mathrm{df}=1, p<.05\right)$. This figure against Batte (2003) research finding that the managers involvement influence ICT - Computer based adoption

The companies' characteristic, especially class of business indicated that there is significan association with Computer adoption with

Table 3. Factor Influences Computer Adoption for Business

\begin{tabular}{|c|c|c|c|c|}
\hline \multirow{2}{*}{$\begin{array}{l}\text { Managerial/organizational } \\
\text { Characteristics }\end{array}$} & \multicolumn{2}{|c|}{ Computer Adoptions } & \multicolumn{2}{|r|}{ Statistics } \\
\hline & Yes & No & df & Sig $(5 \%)$ \\
\hline $\begin{array}{ll}\text { Age } & 51+ \\
& 41-50 \\
& 21-40 \\
\end{array}$ & $\begin{array}{l}15.1 \% \\
87.2 \% \\
7.7 \%\end{array}$ & $\begin{array}{l}18.2 \% \\
64.2 \% \\
17.5 \%\end{array}$ & 2 & $\begin{array}{l}.022^{*} \\
\left(\text { Pearson } X^{2}\right)\end{array}$ \\
\hline $\begin{array}{r}\text { Family relationship : }<10 \% \\
10-20 \% \\
21-30 \% \\
31 \% \\
\end{array}$ & $\begin{array}{l}5.1 \% \\
43.6 \% \\
17.9 \% \\
33.3 \% \\
\end{array}$ & $\begin{array}{l}33.68 \% \\
42.3 \% \\
7.3 \% \\
16.8 \% \\
\end{array}$ & 3 & $\begin{array}{l}.000^{*} \\
\text { (Fisher exact test) } \quad \text { (a) }\end{array}$ \\
\hline $\begin{array}{c}\text { Education: Secondary/college } \\
\text { TAFE } \\
\text { Bachelor } \\
\text { Master+ } \\
\end{array}$ & $\begin{array}{l}32.4 \% \\
81.3 \% \\
21.7 \% \\
4.4 \% \\
\end{array}$ & $\begin{array}{l}36.4 \% \\
18.8 \% \\
78.3 \% \\
95.6 \% \\
\end{array}$ & 1 & $\begin{array}{l}.000^{*} \\
\text { (Fisher exact test) (b) }\end{array}$ \\
\hline $\begin{aligned} & \text { Gender: } \text { Male } \\
& \text { Female }\end{aligned}$ & $\begin{array}{l}15.9 \% \\
43.6 \%\end{array}$ & $\begin{array}{l}84.1 \% \\
56.4 \%\end{array}$ & 1 & $\begin{array}{l}.001^{*} \\
\text { (Fisher exact test) } \quad \text { (c) }\end{array}$ \\
\hline $\begin{array}{l}\text { Association membership } \\
\text { Yes } \\
\text { No }\end{array}$ & $\begin{array}{l}18.5 \% \\
23.9 \%\end{array}$ & $\begin{array}{l}81.5 \% \\
76.1 \%\end{array}$ & 1 & $\begin{array}{l}.258 \\
\left(\text { Pearson } X^{2}\right)\end{array}$ \\
\hline $\begin{array}{r}\text { Class of Business: Large } \\
\text { Medium } \\
\text { Small } \\
\end{array}$ & $\begin{array}{l}21.0 \% \\
30.0 \% \\
3.7 \%\end{array}$ & $\begin{array}{l}79.0 \% \\
70 \% \\
96.3 \%\end{array}$ & 2 & $\begin{array}{l}.019^{*} \\
\left(\text { Pearson } X^{2}\right)\end{array}$ \\
\hline $\begin{array}{l}\text { Types of Business } \\
\text { Horticulture } \\
\text { Fisheries } \\
\text { Livestock } \\
\text { Crops } \\
\end{array}$ & $\begin{array}{l}21.4 \% \\
24.2 \% \\
18.8 \% \\
20.8 \% \\
\end{array}$ & $\begin{array}{l}78.6 \% \\
75.8 \% \\
81.3 \% \\
79.2 \% \\
\end{array}$ & 3 & .934 \\
\hline $\begin{array}{r}\text { Involved: Yes } \\
\text { No }\end{array}$ & $\begin{array}{l}19.3 \% \\
63.6 \%\end{array}$ & $\begin{array}{l}80.7 \% \\
36.4 \%\end{array}$ & 1 & $\begin{array}{l}.003^{*} \\
\text { (Fisher's exact test) (d) }\end{array}$ \\
\hline $\begin{array}{l}\text { Sales volume: } \\
\text { (in million rupiahs) }\end{array}$ & $\begin{array}{l}\text { Mean }= \\
\log 10= \\
\text { Median } \\
\log 10= \\
\text { Mode }=\end{array}$ & $\begin{array}{l}3.1933 \\
6 \\
1.2500 \\
3 \\
0.00\end{array}$ & $\begin{array}{l}\text { Skewness }=.222 \\
\text { SE skw }=.185 \\
\text { Kurtosis }=-1.329 \\
\text { SE kurtosis }=.367 \\
\log 10=4.18\end{array}$ & \\
\hline ICT literacy & $\begin{array}{l}\text { Mean }= \\
\text { Median } \\
\text { Mode }=\end{array}$ & & $\begin{array}{l}\text { Skewness }=-.188 \\
\text { SE skw }=.183 \\
\text { Kurtosis }=1.292 \\
\text { SE kurtosis } \quad=.363 \\
\end{array}$ & \\
\hline
\end{tabular}

* Quota was not achieved the target due to low responses 
significant value $\left(x^{2}=5, \mathrm{df}=2 p<.05\right)$. It accepts Jarvis (1990) research finding that mentioned the type and size of business influence Computer adoption. Class or size of business has indicated no significant influence on intention to adopt Computer for business. However, these indication will argue Baker (1992) and Amposah, (1995) research findings that either types or size of business influenced Computer adoption.

On the other hand Sales volume with mean value $\mathrm{Rp} 5,588.1933$ and skewness between in between $-1<\mathrm{skw}<1$ with $\mathrm{SE}$ skw $=.185$, kurtosis $-1.329 \mathrm{SE}$ kurtosis .367 means that the variable is not normally distributed. The sales volume was transformed into log 10 to smooth the data. The bivariate analysis result is then confirmed to the multivariate analysis using Binomial Logistic regression.

\section{b) Binomial Logistic Regression Result}

Result from the binomial Logit model showed that 80.4 percent of all the farmers were predicted correctly not to adopt Computer with the odd of successful prediction would be significantly $(p=0.00)$. It means that the probability of adopting Computer not fully supported by all explanation variables. There are seven of the thirteen variables (types of business, gender, literacy, involved, saleslog, dummy age and dummy education are, individually significant predictors of whether farmers would not adopt Computer. The res has possibility to support the adoption. It can be seen that the Omnibus Test of Model that, when we consider all thirteen predictors together, the model or equation is significant $\left(X^{2}=61.958, \mathrm{~d}\right.$ $=12, p<.001)$. From the estimating percent of variant accounted for, the "pseudo $R^{2}$ indicate that approximately 53 percent of the variance mentioned whether or not farmers adopt Compute can be predicted from the linear combination of the thirteen factors. On the other hand the independent variables/covariates who would not adopt Computer were predicted 96.7 percent correct than at who would adopt Computer were predicted 53.3 percent correct with 88.2 percent of the participants were predicted correctly.

From the Logit result, found that Sales volume has significantinfluence onintentiontoadoptComputer for business at $\alpha$ level $=.05$ (.004) with odd ratio is .337 (accept H3). It means that any additional of 1 sales volume will reduce the probability of adopting Computer by 0.337 times. It argues the research findings of Mbowa and Mugisha (2004). On the other hand, Type of business and Size of business with reference category large business indicated no significant influence on intention to adopt Computer for business (reject $H 2$ ). It means that any increasing types of business in a large size of business research participants will not influence on increasing probability on adopting Computer for business (reject $\mathrm{H1}$ ). The managers involvement with normally has relevancy with size of business also did not influence significantly on intention to adopt Computer for business (reject $H 7$ )

Family membership (reject H4) and association membership (reject H5) also did not have significantly influence. These mean that any increasing number of employee has a family relationship and any increasing association membership will not influencing the intention to adopt the Computer for business.

Gender (sex) is not significantly influence on intention to adopt the Computer for business neither 90 or $95 \%$ confidence intervals due to gender is dichotomous; ' 1 ' for male and '2' for female (reject $H 9$ ). This findings supports Brown and Buys (2005). On the other hand the dummy variables of manager's Age $41+$ has significant influence on intention to adopt Computer for business $(p<.05)$ with odd ratio 5.416 and positive $B$ coefficient=1.689 (accept H8). It means that any improvement of manager's age more than 41 will improve probability of adopting Computer by 5.41.6 times. This finding will argue and Jarvis (1990). While manager's Education significantly influences on intention to adopt Computer

Table 4. Logistic Regression Predicting ICT Adoption

\begin{tabular}{lrrrrrr}
\hline \multicolumn{1}{c}{ Variables } & \multicolumn{1}{l}{ B } & \multicolumn{1}{l}{ Wald } & \multicolumn{1}{l}{ df } & Odd ratio & \multicolumn{1}{l}{$P$} \\
\hline Types of Business & & & 6.497 & 3 & & .090 \\
\hline Type(1) & 1.642 & 1.175 & 1.954 & 1 & 5.164 & .162 \\
\hline Type (2) & .160 & 1.102 & .021 & 1 & 1.174 & .884 \\
\hline Type(3) & -.691 & 1.406 & .241 & 1 & .501 & .623 \\
\hline Association membership & 1.165 & .700 & 2.477 & 1 & 3.207 & .096 \\
\hline Sex & 1.059 & .673 & 3.759 & 1 & 2.882 & .116 \\
\hline Literacy & 1.001 & .516 & .003 & 1 & 2.722 & .053 \\
\hline Manager's involvement & -.075 & 1.426 & 2.769 & 1 & .927 & .958 \\
\hline Sales Volume & -1.086 & .381 & .640 & 1 & .337 & .004 \\
\hline Age_41+ & 1.689 & .819 & .327 & 1 & 5.416 & .039 \\
\hline Size of Business & -.680 & 1.189 & 4.258 & 1 & .507 & .567 \\
\hline TAFE Education & 3.474 & 1.035 & 8.139 & 1 & 32.256 & .001 \\
\hline Family membership & -.021 & .027 & 11.272 & 1 & .979 & .424 \\
\hline Constant & -5.310 & 2.937 & 3.268 & 1 & .005 & .071 \\
\hline
\end{tabular}

Variable(s) entered on step 1: TYPES, SEX, Literacy, INVOLVED, ASSOC, family3, DM3class, DM_41, saleslog, DMEd2.

for business $(p<.005)$ on manager's decision making on adopting computer (accept H10). The Education level (TAFE/D3) has an odd ratio by 32.256 means that any increasing of farmers education level up to TAFE will increase the chance of adopting Computer by 32.256 times. This findings will argue Jarvis's (Jarvis 1990) research conclusion but accept research finding by Amposah (1995) . However, the ICT literacy did not significantly influence on intention to adopt Computer for business at $95 \%$ confidence intervals $(\alpha=05)$ (reject $H 6)$.

\section{MANAGERIAL IMPLICATIONS}

According to the research findings, the following recommendations have to be conducted:

East java agribusinesses have to increase the manager's education level up to D3 in regards witrh the effort on digitally business improvement in facing the globalization era. The East Java agribusinesses have to place the manager with the age more than 41 . This imply that the age $41+$ is the mature age in decision making on influencing the intention of adopting advance technology such as Computer on increasing the compietitive advantage.

Even the sales volume has indicated to have litle influence on intention to adopt Computer, the agribusiness owner managers in East Java have to put more effort on increasing sales volume. Most agribusiness in East Java lay on their revenue from sales as a financial resource. This lead to positively influence in adopting advance technology such as the Computer adoption.

\section{CONCLUSION}

Based upon statistical analysis the study producing some following conclussion:

From the binomial analysis, there are six categorical variables that are indicated for having association towards Computer adoption in Eas Java agribusiness. Some of the the variables are inconsistent when they employed in Logit.

Only age, sales volumes and education remain for having the significant influence on intention to adopt computer for business. It means that 
there are overstates when bivariate analysis were employed.

The Class of business variable is inconsistent in analysis result at the bivariate and logit analysisdue to mistake in choosing the reference category.
The Manager involvement and Gender' variables have binary data caused high SE relevant high relative to $B$ whether the Wald statistics is relatively high. It also caused the dichotomous variable of gender and involved makes SE relatively high. $匚$
This paper is part of author's dissertation and was presented in $21^{\text {st }}$ ANZAM Conference on Managing Our Intellectual and Social Capital, 4 - 7 December 2007 , Sydney, Australia. Author would like to thanks to Professor Jerry Courvisanos from The
University of Ballarat, Victoria, Australia and the late of Professor Soekartawi for his past contribution and guidance. Author also would like to thank to the anonymous reviewers on accepting this paper presented in the conference.

\section{REFERENCES}

Amponsah, W. A. (1995). Computer Adoption and the Use of Information Servives by North Carolina Comercial Farmers. Journal of Agricultural and Applied Economics. 27(2), $565-567$.

Baker, G. A. (1992). Computer Adoption and Use by New Mexico Nonfarm Agribusiness, American Journal of Agricultural Economics. $74(3) .737-744$.

Bandura, A. (1986). Social Foundations of Thought and Action: A social Cognitive Theory. Englewood Cliffs, NJ: PrenticeHall. Batte, M. T. (2003). Computer on Ohio Farms: How Used and How Usefull? OSU AED Economics (AEDE-RP-0040-03). Batte, M. T. (2005). Changing Computer Use in Agriculture. InfoAg. Springfield, LL.

Bourakis, G., M. Kourgiantakis, et al. (2002). "The Impact of E-commerce on Agro-food Marketing; The Case of Agricultural akis, G., M. Kourgiantakis, et al. (2002). "The Impact of E-commerce on Agro-food M.
Cooperatives, Firms and Consumers in Crete." British Food Journal, 104(8): 580-590.

Brown, I. and M. Buys (2005). A Cross-Cultural Investigation into Customer Satisfaction with Internet Banking Security

CBS (2002). Statistical year book of Indonesia 2002. Jakarta, Central Bureau of Statistics Indonesia.

Deodar, S. Y. (2001). WTO Agreements on SPS and TBT: Implications for Food Quality Issues, IIM-Working Paper. Ernst, S. and M. Tucker (2001). Perception and Adoption of Information Tecnologies: Implication for Ohio's Producer Industry in the New Economy. International Meeting of Agricultural Communicators in Education. Toronto, Canada.

Ernst, S. and M. Tucker (2002). Agri-Culture; A New Look at Adoption and Diffusion of Information Technology. International Meeting of Agricultural Communication in Education. Savanah, Georgia, USA.

FAO (2001). Food and Agriculture Organization of the United Nations Regional Office for Asia and the Pacific. Bangkok, Thailand, FAO Regional Office forAsia and the Pacific.

Gloy, B. A. and J. T. Akridge (2001). Drivers of Internet Adoption on Large U.S. Farms and Implications for Agribusiness. World Food and Agribusiness Forum, Chicago, IL.

Hermana, B., T. Sugiharto, et al. (2006). Determinants of Internet Adoption by Indonesian Small Business Owners: Reliability
and Validity of Research Instrument. E-prints in Library and Information Science. Retrieved 25 Sept 08, 2008, from Http:// and Validity of Research Instrument. E-prints in Library and Information Science. Red
eprints.rclis.org/archive/00013481/01/Indon esiaan_small_bussines__ct__adoption.pd

Hofstede, G. (1991). Culture and Organization. London: McGraw-Hill.

Hosmer, D. W. and S. Lemeshow (1989). Applied Logistic Regression. New York USA: John Wiley and Sons.

Jarvis, A. M. (1990). Computer Adoption Decision-Implication for Reseach and Extension: The

Case of Texas Rice Producers. American Journal of Agicultural Economics. 72(5), 1388-1394.

Kartiwi, M. (2006). Case Studies of E-Commerce Adoption in Indonesia SMEs: The Evaluation of Strategic Use. Australasian Journal of Information Systems 14(1): 69-80.

Kmenta, J. (1971). Elements of Econometrics. New-York: The Macmillan Company.

Lim, J. (2004). The Role of Power Distance and Explanation Facility in Online Bargaining Utilizing software agents. Journal of Global Information Management. 12(2): 27-43.

Mbowa, S. and J. Mugisha (2004). Determinants of Use of Information Technologies by Agribusiness Firm in Uganda. EAJRD 20(December 2004): 3-11
Palvia, P. C. (1997). Developing a Model of the Global and Strategic impact of information Technology. Information and Management (October): 229-244.

Phillip, N. E. (2003). Those Most Likely: Identifying Food Processing Firms With export Potential. Agribusiness Review 11.

Pohlmann, J. T. (2003). A Comparison of Ordinary Least Square and Logistic Regression. Annual Meeting of American Educational Research Association Chicago, Illinois.

Putler, D. S. and D. Zilberman (2001). Computer Use in Agriculture: Evidence from Tulare County, California. America Journal of Agricultural Economics.

Rogers, E. M. (1995). Diffusion of Innovations. New York, The Free Press

Salampasis, M., C. Batzios, et al. (2002). Identifying Use and Impact of the Internet Greek Agricultural Sector: preliminary Resul of A Survey of websit Owners. HAICTA, Athens.

Sudaryanto (2010). Factors Influencing ICT Adoption in East Java Agribusiness: Individual and School of Business. Ballarat, Victoria, Australia, University of Ballarat. Ph.D: page. 296.

Veal, A. J. (2006). Research Method for Leisure and Tourism: A Practical Guide. Harlow, England: Prentice Hall/Pearson Education.

Wahid, F. (2007). Using the Technology Adoption Model to Analyze Internet Adoption and Use among Men and Women in Indonesia. The Electronic Journal of Information Systems in Developing Countries 32. 